\title{
Species-Specific Primers for Eutypella parasitica, the Causal Agent of Eutypella Canker of Maple
}

\author{
Barbara Piškur, Nikica Ogris, and Dušan Jurc, Slovenian Forestry Institute, Večna pot 2, SI-1000 Ljubljana, \\ Slovenia
}

\begin{abstract}
Piškur, B., Ogris, N., and Jurc, D. 2007. Species-specific primers for Eutypella parasitica, the causal agent of Eutypella canker of maple. Plant Dis. 91:1579-1584.

Eutypella parasitica was recently reported in Europe for the first time, and this study reports the molecular evaluation of the internal transcribed spacer (ITS)1/5.8S/ITS2 regions of 68 isolates of the fungus obtained in pure culture with polymerase chain reaction restriction fragment length polymorphism (RFLP). The RFLP patterns of all isolates proved identical and the restriction profiles served to differentiate E. parasitica from Eutypa lata, another pathogenic member of the family Diatrypaceae. Low intraspecific variability was detected in the sequenced ITS1/5.8S/ ITS2 regions of eight Eutypella parasitica isolates originating from different hosts and geographical locations. Based on this ITS region, EpR/F primers specific to E. parasitica were constructed and tested with a wide range of fungal isolates. The EpR/F primer pair successfully amplified the expected fragment size of $341 \mathrm{bp}$ from isolates of E. parasitica and also directly from infected maple wood shavings. The RFLP patterns and species-specific primers represent a step toward routine, large-scale, and rapid molecular diagnostics and identification of $E$. parasitica.
\end{abstract}

The family Diatrypaceae (Ascomycota) includes several genera that typically occur on a broad range of declining or dead woody angiosperms; most are considered saprobes, except Eutypa lata and Eutypella parasitica, which are pathogens $(1,4)$. Molecular phylogenetic studies of Diatrypaceae (1) showed little correlation with the current morphology-based classical taxonomic scheme; however, there are no reports of phylogenetic placing of E. parasitica within the family.

E. parasitica causes the Eutypella canker of maple (Acer spp.), a destructive disease originally found in North America $(5,19,39)$. In Europe, the disease was reported recently from several locations in Slovenia (17). Moreover, field maple (Acer campestre) was reported for the first time as a host of E. parasitica (30). In Europe, extensive areas of maple stands are predicted to be at considerable risk from $E$. parasitica infection (31). Although the potential economic loss due to the Eutypella canker is yet to be estimated for Europe, it is desirable to track the disease

Corresponding author: B. Piškur

E-mail: barbara.piskur@gozdis.si

EMBL accession numbers for nucleotide sequences: AM295770, AM295771, AM295772, AM295773, AM295774, AM295775, AM295776, and AM295777

Accepted for publication 30 June 2007.

doi:10.1094/PDIS-91-12-1579

(C) 2007 The American Phytopathological Society and to initiate measures to avoid its spread, which could threaten Acer spp. growing in forests, urban environments, or nurseries (31).

The first visual sign of Eutypella canker is dieback of the bark and, due to the slow progression of the fungus, the site of initial infection often escapes notice. The necrosis slowly advances with growth of the tree and, 5 to 8 years after the dieback of the bark, numerous perithecial necks surrounded by poorly developed stromata are seen on the surface of the canker. A characteristic sign of the canker is mycelial fans in the infected bark $(17,23,30)$. The fungus overgrows the wood underneath the wound, causing a brown discoloration and slow degradation of wood (19).

Eutypa lata has been reported on a broad range of tree species, but it is not yet clear whether all isolates are pathogenic $(4,28)$. According to the Centraalbureau voor Schimmelcultures (CBS) Filamentous Fungi Database, E. lata var. aceris Rappaz can appear on A. campestre and A. pseudoplatanus. Carter et al. (4) confirmed the pathogenicity of one strain of E. lata, isolated from A. campestre, on apricot and grapevine. Like Eutypella parasitica on maple, Eutypa lata causes cankers on grapevines and apricot, and typically is observed as perithecia embedded in the stromata composed of fungal and host tissues, with numerous spindle-shaped, eight-spored asci with long stipes (28). The described symptoms and signs of $E$. lata are similar to those of Eutypella parasitica, and could be the reason for misidentification of the fungus, although we have not found any report of Eutypa lata being pathogenic to the maple.

Eutypella parasitica was placed on the alert list of the European and Mediterranean Plant Protection Organization in 2005 (29) and a quick and reliable method for its detection and identification would be required to implement the quarantine measures. Conventional methods of identifying E. parasitica and other plant-pathogenic fungi include observations of visible symptoms on the host and isolation and culturing of the pathogen, followed by a macro- and microscopic examination of the mycelium and fruiting structures in the culture. Inoculation of the host with the isolated fungus and reisolation from the infected host usually confirms pathogenicity. These procedures are time consuming, and successful identification requires experience, knowledge, and skill (26). Identification based on the comparison of molecular markers is much faster, does not require fully developed morphological features, and can be used with any infected material by workers with limited experience in plant pathology. Methods such as restriction fragment length polymorphism (RFLP) of the polymerase chain reaction (PCR) products or a PCR with speciesspecific primers also can provide confirmation of the presence of the pathogen and are potential candidates for automation. A number of species-specific primers have been developed for identifying plant pathogens and the first online database of primers for plant pathogenic fungi has been released (8).

The objectives of this work were to (i) confirm the identification of E. parasitica, obtained by using morphology of the isolates in pure culture with that obtained by using PCR-RFLP; (ii) conduct a preliminary screening of the variability of internal transcribed spacer (ITS) region among isolates of E. parasitica using PCR-RFLP and to sequence this region; (iii) develop primers specific to $E$. parasitica based on the rDNA ITS region for rapid and largescale identification of the pathogenic fungus from various sources, including infected plant material; and (iv) extract DNA directly from diseased wood for developing a method for direct detection of $E$. parasitica.

\section{MATERIALS AND METHODS}

Fungal isolates. We used 68 isolates of E. parasitica obtained from different loca- 
tions in Slovenia from which outbreak of the disease had been reported (Table 1), isolated either from infected wood or dibark. We also included E. parasitica extype isolate CBS 210.39 as a reference strain. The isolates were grown at $24^{\circ} \mathrm{C}$ on malt extract agar (20.0 g of malt extract, ter) and then stored at $4{ }^{\circ} \mathrm{C}$ until needed. Thirty-three diverse fungal isolates (Table 2) were used for testing the specificity of the constructed species-specific primers. Additionally, fresh plant material comprising infected and uninfected wood and leaves was used for testing the sensitivity of the method with primers specific to $E$. parasitica or as a negative control.

DNA extraction. DNA was extracted from approximately $1 \mathrm{~cm}^{2}$ of the mycelium scraped from the surface of the agar plate or, in the case of field samples, from either approximately $4-\mathrm{mm}^{2}$ pieces of wood shavings from infected wood tissue at the margins of the discoloration or young leaves. The plant material was handled aseptically throughout the process. DNA was extracted using the $2 \%$ (wt/vol) hexaprotocol $(6,35)$. To the initial DNA from the plant material extracted in a buffer, $1 \%$ (wt/vol) polyvinylpoly-pyrrolidone (PVPP) was added (13) and the extracted DNA was resuspended in $50 \mu \mathrm{l}$ of sterile distilled water. DNA concentrations in DNA samples extracted from pure E. parasitica cultures and infected wood tissue were measured spectrophotometrically (Hewlet Packard 8453) by using the molar extinction coefficient expressed in molar concentration of base pairs (calf thymus and rectly from perithecia embedded in the $15.0 \mathrm{~g}$ of agar, and 1 liter of distilled wadecyltrimethylammonium bromide (CTAB)

salmon testes DNA; $\varepsilon_{259}=12,800 \mathrm{M}^{-1} \mathrm{~cm}^{-1}$; $34)$ and pure distilled water as a reference solution. In addition to the $2 \%$ CTAB protocol, DNA also was extracted from the wood shavings by using the method described by Lecomte et al. (24). Serial dilutions of the DNA samples from pure $E$. parasitica cultures and wood shavings were prepared. Extracted uninfected maple genomic DNA was spiked with serial dilutions of extracted E. parasitica genomic DNA to check the influence of possible inhibitors on PCR reaction. Original solutions and dilutions were used for PCR reactions.

PCR amplification, restriction, and sequencing. Amplifications were performed with universal fungal primers ITS1f (7) and ITS4 (40) in 10- or 40- $\mu$ l reaction volumes, depending on the method for which it was to be used next. The $10-\mu l$ reaction mix comprised $6.35 \mu \mathrm{l}$ of sterile double-deionized $\mathrm{H}_{2} \mathrm{O}, 1 \mu \mathrm{l}$ of 10× PCR buffer, $1 \mu \mathrm{l}$ of $25 \mathrm{mM} \mathrm{MgCl}_{2}, 1$ $\mu \mathrm{l}$ of $2 \mathrm{mM}$ dNTPs, $0.2 \mu \mathrm{l}$ each of $10 \mu \mathrm{M}$ ITS1 and $10 \mu \mathrm{M}$ ITS 4 primers, $0.05 \mu \mathrm{l}$ of Taq DNA polymerase ( $5 \mathrm{U} / \mu \mathrm{l}$; Eppendorf), and $0.2 \mu \mathrm{l}$ of DNA extract per reaction. The 40- $\mu$ l reaction mix comprised the same ingredients in the same proportions. The cycling parameters followed the procedure described by Kraigher et al. (21). Initial DNA denaturation was at $94^{\circ} \mathrm{C}$ for $85 \mathrm{~s}$; followed by 35 cycles of denaturation $\left(95^{\circ} \mathrm{C}\right.$ for $\left.35 \mathrm{~s}\right)$, primer annealing $\left(55^{\circ} \mathrm{C}\right.$ for $55 \mathrm{~s}$ ), and DNA extension at $72^{\circ} \mathrm{C}$ (for $45 \mathrm{~s}$ for the first 13 cycles, $120 \mathrm{~s}$ for the next 13 cycles, and for $180 \mathrm{~s}$ for the final 9 cycles); and final DNA extension at $72^{\circ} \mathrm{C}$ for $10 \mathrm{~min}$. All PCRs, including negative and positive controls, were checked for

Table 1. Isolates of Eutypella parasitica from the wood of infected trees or directly from perithecia

\begin{tabular}{|c|c|c|}
\hline Designation $^{a}$ & Acer spp. host & Geographic origin \\
\hline D1/1 & Acer pseudoplatanus & Ljubljana, SI \\
\hline $\mathrm{D} 4 / 1,2,3,4$ & A. pseudoplatanus & Ljubljana, SI \\
\hline D5/1 & A. pseudoplatanus & Ljubljana, SI \\
\hline D6/1 & A. pseudoplatanus & Ljubljana, SI \\
\hline $\mathrm{D} 7 / 1,2,3,4$ & A. pseudoplatanus & Ljubljana, SI \\
\hline $\mathrm{D} 11 / 1,2,3$ & A. pseudoplatanus & Ljubljana, SI \\
\hline $\mathrm{D} 14 / 1,2,3,4$ & A. pseudoplatanus & Ljubljana, SI \\
\hline D15/1 & A. pseudoplatanus & Ljubljana, SI \\
\hline $\mathrm{D} 24 / 1,2,3,4,5,6$ & A. pseudoplatanus & Ljubljana, SI \\
\hline $\mathrm{D} 26 / 1^{*}, 2,3,4,5$ & A. pseudoplatanus & Ljubljana, SI \\
\hline $\mathrm{G} 7 / 2$ & A. pseudoplatanus & Ljubljana, SI \\
\hline $\mathrm{IZ} 1 / 1,2,3$ & A. pseudoplatanus & Sevnica, SI \\
\hline $\mathrm{IZ} 2 / 1,2,3$ & A. pseudoplatanus & Sevnica, SI \\
\hline $\mathrm{K} 1 / 1^{*}, 2,3$ & A. pseudoplatanus & Kozje, SI \\
\hline $\mathrm{M} 1 / 1^{*}, 2,3$ & A. campestre & Ljubljana, SI \\
\hline $\mathrm{M} 2 / 1,2,3,4,5,6$ & A. campestre & Ljubljana, SI \\
\hline $\mathrm{M} 3 / 1,2,3,4,5$ & A. campestre & Ljubljana, SI \\
\hline $\mathrm{OJ} 1 / 1^{*}, 2$ & A. platanoides & Ljubljana, SI \\
\hline $\mathrm{RS} 1 / 1^{*}, 2,3$ & A. campestre & Rogaška Slatina, SI \\
\hline SE1/1 & A. pseudoplatanus & Sevnica, SI \\
\hline $\mathrm{SE} 2 / 1^{*}, 2,3$ & A. pseudoplatanus & Sevnica, SI \\
\hline TO1/1*, 2, 3 & A. pseudoplatanus & Topol, SI \\
\hline $\mathrm{ZN} 1 / 1^{*}, 2$ & A. campestre & Znojile pri Krki, SI \\
\hline
\end{tabular}

${ }^{a}$ Each number after the slash represents a separately cultured isolate and the entire series after the slash indicates isolates obtained from the same canker. All isolates were analyzed with polymerase chain reaction restriction fragment length polymorphism; asterisks indicate the isolates sequenced and used for constructing species-specific primers. positive amplification on a $0.5 \times$ Tris-borate EDTA (TBE) (Sigma) 2\% (wt/vol) agarose gel (LE; Promega) stained with ethidium bromide. Only those reactions that yielded single and strong bands on the gel were used for subsequent analysis.

For restriction analyses, 5- $\mu$ l aliquots of the PCR products were digested in separate reactions with $\operatorname{HinfI}, \mathrm{MboI}$, and TaqI endonucleases (18) according to the manufacturer's instructions (Promega). The gels were read and the data on fragment size from Polaroid or GelDoc photos were processed using Adobe Photoshop and analyzed in the Taxotron software system, which is designed especially for processing RFLP data (14), as described in Grebenc et al. (12), and subsequently compared with the PCR-RFLP database at the Slovenian Forestry Institute (SFI) $(9,11,12)$. Fragments shorter than $100 \mathrm{bp}$ were not included in the restriction analysis.

Amplified DNA from the isolates intended for sequencing (Table 1) was cleaned using Wizard SV Gel and PCR Clean-Up System (Promega) kit. Both strands of the amplicons were sequenced on ABI Prism 310 using BigDye Terminator v3.1 Matrix Standard Kit (Applied Biosystems). The sequences were aligned with the corresponding sequences of Eutypella spp. accessed from the GenBank database (Table 3) using DIALIGN2 (27).

The constructed primers specific to $E$. parasitica were compared against the GenBank "nr" database by searching for short and nearly exact matches using BLASTN. The primers were checked for specificity against the isolates of E. parasitica (Table 1) and other fungal or plant material (Table 2). In the specific PCR, cycling parameters were the same as those used in the amplification with primers ITS1f and ITS4, but with different annealing temperatures (55, 60 , or $63^{\circ} \mathrm{C}$ ).

\section{RESULTS}

The PCR-RFLP with MboI, HinfI, and TaqI restriction enzymes (Figs. 1, 2, and 3) of the 650-bp long ITS region, amplified with the ITS1f and ITS4 primers, showed a uniform restriction pattern for all isolates of E. parasitica (Table 4). The restriction profile of E. parasitica obtained with HinfI was clearly different from that of E. prunastri (CBS. 277.87), Eutypa lata (CBS. 208.87), and E. lata var. aceris (CBS 290.87, CBS 217.87) obtained with the same restriction enzyme (Table 4; Fig. 2). Restriction enzymes $M b o \mathrm{I}$ and $T a q \mathrm{I}$ revealed either no differences or only minor differences in RFLP patterns among isolates of Eutypella parasitica, E. prunastri, Eutypa lata, and E. lata var. aceris included in this analysis (Table 4; Figs. 1 and 3).

The sequences of the ITS1/5.8S/ITS2 region of selected isolates of Eutypella parasitica (Table 1) from different locations and host species were identical to $E$. parasitica sequences from GenBank (Ta- 
ble 3). An exception was isolate TO1/1, which differed from the rest in its cytosineto-thymine transition at site 14 in the ITS2 sequence region, confirmed by both sequenced amplicon strands. The point mutation did not affect the RFLP pattern (Table 4). The sequences were deposited in the EMBL Nucleotide Sequence Database under accession numbers AM295770AM295777.

Based on the sequence alignment of $E$. parasitica with other Eutypella spp. sequences in Table 3, the forward primer EpF 5'-CGCCGAAGGACTGTTAAACT$3^{\prime}$ and the reverse primer EpR 5'CTGACACCACTGAAGCGAGA-3' were constructed. Amplification with these specific primers yielded the expected fragment of $341 \mathrm{bp}$ for all isolates of E. parasitica (Fig. 4). The other fungi included in the analysis (Table 2) and DNA extracts from host species yielded no amplification products, except for E. prunastri, which targeted an amplicon at an annealing tem- perature of $55^{\circ} \mathrm{C}$ but not at 60 or $63^{\circ} \mathrm{C}$ (Fig. 4). Amplification with primers specific to E. parasitica using DNA extracts made directly from infected wood using the $2 \% \mathrm{CTAB}$ extraction protocol required up to $100 \times$ serial dilution for some extracts to yield the expected fragment. The DNA concentrations (in base pairs) were around $160 \mu \mathrm{M}_{\mathrm{bp}}$ for DNA extracts made from pure cultures of E. parasitica and $45 \mu \mathrm{M}_{\mathrm{bp}}$ for DNA samples extracted from wood shavings infected with $E$. parasitica. Diluting of DNA samples indicated the detection limit for the PCR assay with EpR/F to be around $0.04 \mu \mathrm{M}_{\mathrm{bp}}$ (Fig. 5). DNA extracts from infected wood diluted up to $100 \times$ following the method of Lecomte et al. (24) revealed no products after PCR assays with either specific or universal primers.

\section{DISCUSSION}

Our aim to construct primers specific to E. parasitica, the causal agent of Eutypella canker of the maple, and to select a proto-

Table 2. Species or isolates of fungi comprising some members of Diatrypaceae and other ubiquitous fungi or those associated with wood used for confirming specificity of primers specific to Eutypella parasitica $^{\mathrm{a}}$

\begin{tabular}{|c|c|c|}
\hline Species or isolate & Origin $^{b}$ & Comments ${ }^{\mathrm{c}}$ \\
\hline Acremonium sp. & SFI TBR1 & Co-isolated with Eutypella \\
\hline Alternaria alternata & ZIM 101 & Kept at $4^{\circ} \mathrm{C}$ on $\mathrm{PDA}$ \\
\hline Antrodia vaillantii & ZIM 80 & Kept at $4^{\circ} \mathrm{C}$ on PDA \\
\hline Armillaria mellea & ZIM 1 & Kept at $4^{\circ} \mathrm{C}$ on PDA \\
\hline Aureobasidium pullulans & ZIM 103 & Kept at $4^{\circ} \mathrm{C}$ on PDA \\
\hline Botryosphaeria dothidea & SFI B $1 / 4$ & Isolated with Ostrya carpinifolia \\
\hline Chaetomium globosum & $\mathrm{SFI} \mathrm{C/1}$ & Co-isolated from Eutypella \\
\hline Eutypa lata & CBS 208.87 & $\ldots$ \\
\hline E. lata var. aceris & CBS 217.87 & Isolated with Acer campestre \\
\hline E. lata var. aceris & CBS 290.87 & Isolated with A. pseudoplatanus \\
\hline Eutypella prunastri & CBS 277.87 & $\ldots$ \\
\hline Exophiala sp. & SFI PBR/1 & Co-isolated from Eutypella \\
\hline Exophiala sp. & SFI E/2 & Co-isolated from Eutypella \\
\hline Fomes fomentarius & ZIM 59 & Kept at $4^{\circ} \mathrm{C}$ on PDA \\
\hline Ganoderma applanatum & ZIM 15 & Kept at $4^{\circ} \mathrm{C}$ on PDA \\
\hline Heterobasidion annosum & ZIM 19 & Kept at $4^{\circ} \mathrm{C}$ on PDA \\
\hline Hypoxylon fragiforme & ZIM 508 & Kept at $4^{\circ} \mathrm{C}$ on PDA \\
\hline Nectria galligena & SFI Nectria/1 & Co-isolated with Eutypella \\
\hline N. galligena & SFI Nectria/2 & Co-isolated with Eutypella \\
\hline Penicillium janthinellum & ZIM 410 & Kept at $4^{\circ} \mathrm{C}$ on $\mathrm{PDA}$ \\
\hline Phanerochaeteae chrysosporium & ZIM 1015 & Kept at $4^{\circ} \mathrm{C}$ on PDA \\
\hline Pleurotus ostreatus & AG PLA B & Kept at $4^{\circ} \mathrm{C}$ on PDA \\
\hline P. ostreatus & AG Plo S2 & Kept at $4^{\circ} \mathrm{C}$ on PDA \\
\hline P. ostreatus & AG Plo 3 & Kept at $4^{\circ} \mathrm{C}$ on PDA \\
\hline P. ostreatus & ZIM 1002 & Kept at $4^{\circ} \mathrm{C}$ on PDA \\
\hline P. ostreatus & ZIM 1006 & Kept at $4^{\circ} \mathrm{C}$ on PDA \\
\hline P. ostreatus & ZIM 76 & Kept at $4^{\circ} \mathrm{C}$ on PDA \\
\hline Saccharomyces cerevisiae & ZIM 0074 & Kept at $4^{\circ} \mathrm{C}$ on $\mathrm{YM}$ \\
\hline Schyzophyllum commune & SFI E/1 & Co-isolated with Eutypella \\
\hline S. commune & ZIM 41 & Kept at $4^{\circ} \mathrm{C}$ on $\mathrm{PDA}$ \\
\hline Stropharia rugosoannulata & AG STRA 1 & Kept at $4^{\circ} \mathrm{C}$ on PDA \\
\hline Trametes versicolor & ZIM 97 & Kept at $4^{\circ} \mathrm{C}$ on PDA \\
\hline Trichoderma longibrachiatum & ZIM 413 & Kept at $4^{\circ} \mathrm{C}$ on PDA \\
\hline
\end{tabular}

a The isolates were grown at $24^{\circ} \mathrm{C}$ on malt extract agar and then stored at $4^{\circ} \mathrm{C}$ until further use or as specified.

b Abbreviations of culture collections: AG, collection at the Institute of Natural Sciences, Ljubljana, Slovenia; CBS, collection at the Centraalbureau voor Schimmelcultures, Utrecht, The Netherlands; SFI, collection of plant-pathogenic fungi at the Slovenian Forestry Institute, Ljubljana, Slovenia; ZIM, collection at the Department of Wood Science and Technology and at the Department of Food Science and Technology, Biotechnical Faculty, Ljubljana, Slovenia (33).

c Abbreviations of culture media: PDA = potato dextrose agar (Difco); YM = yeast maltose agar (3.0 g of yeast extract, $3.0 \mathrm{~g}$ of malt extract, $5.0 \mathrm{~g}$ of peptone, $10.0 \mathrm{~g}$ of glucose, $20.0 \mathrm{~g}$ of agar, and 1 liter of distilled water); and co-isolated with Eutypella = co-isolated from discolored wood from a Eutypella canker. col suitable for DNA extracts from wood shavings was achieved. We amplified DNA fragments of the expected size from extracts made directly from wood shavings (from tissues taken from the margin of the brown discolorations typical of Eutypella canker). The BLAST search showed high specificity of the designed primer pair $\mathrm{EpF} / \mathrm{R}$ among the sequences deposited in the GenBank database. The specificity of primer pair EpF/R also was confirmed with tested fungal isolates used in this study. Clear amplification was achieved

Table 3. Internal transcribed spacer (ITS)1/ 5.8S/ITS2 sequences and accession numbers in the GenBank nucleotide database of Eutypella spp. used for multiple sequence alignment and search of regions specific to Eutypella parasitica

\begin{tabular}{lc}
\hline Fungal species & $\begin{array}{c}\text { GenBank } \\
\text { accession number }\end{array}$ \\
\hline Eutypella vitis & AY462578 \\
E. vitis & AY462577 \\
E. scoparia & AF373064 \\
E. scoparia & AJ302465 \\
E. quaternata & AJ302469 \\
E. prunastri & AJ302464 \\
E. leprosa & AJ302463 \\
E. kochiana & AJ302462 \\
E. cerviculata & AJ302461 \\
E. cerviculata & AJ302468 \\
E. caricae & AJ302460 \\
E. alsophila & AJ302467 \\
E. parasitica & DQ118964 \\
E. parasitica & DQ118965 \\
E. parasitica & DQ118966 \\
\hline
\end{tabular}

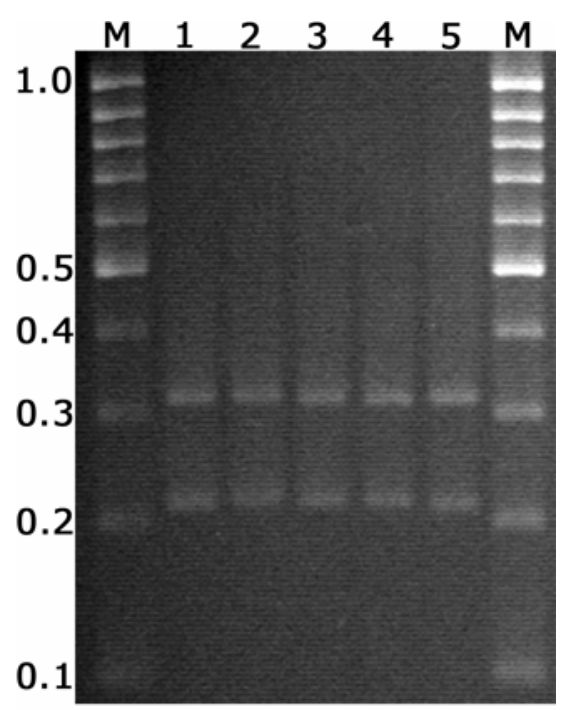

Fig. 1. MboI restriction fragment length polymorphism patterns of polymerase chain reactionamplified internal transcribed spacer (ITS)1/ 5.8S/ITS2 regions using primer pair ITS1f/ITS4 from DNA isolated from pure cultures. Digests were run on a $2 \%$ agarose gel in $0.5 \times$ Tris-borate EDTA buffer. Lane M, molecular ladder, Kbp units (Gene Ruler 100-bp DNA Ladder; Fermentas); lane 1, Eutypella prunastri (CBS. 277.87); lane 2, Eutypa lata (CBS. 208.87); lane 3, E. lata var. aceris (CBS 290.87); lane 4, E. lata var. aceris (CBS 217.87); and lane 5, Eutypella parasitica (SFI D26/1). 
with all E. parasitica isolates and no reaction was observed with 33 isolates of other fungi. Methods based on PCR using species-specific primer pairs for fungi enabled rapid detection and identification of fungal pathogens (25) even before the infected plants show significant symptoms $(15,37)$.

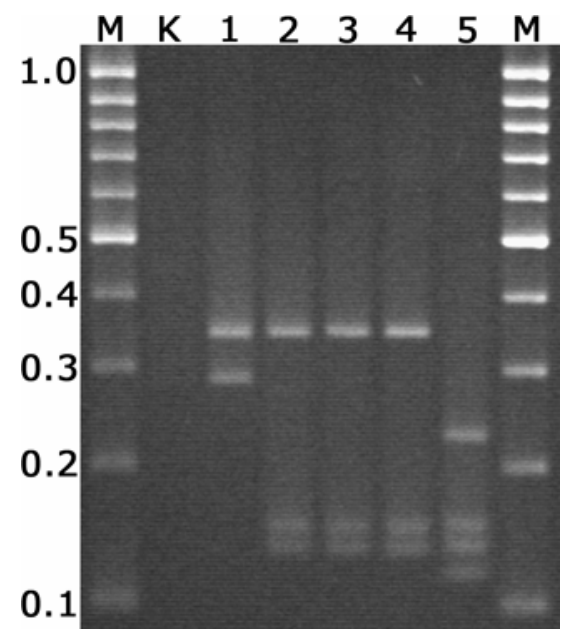

Fig. 2. HinfI restriction fragment length polymorphism patterns of polymerase chain reaction-amplified internal transcribed spacer (ITS)1/5.8S/ITS2 regions using primer pair ITS1f/ITS4 from DNA isolated from pure cultures. Digests were run on a $2 \%$ agarose gel in $0.5 \times$ Tris-borate EDTA buffer. Lane M, molecular ladder, Kbp units (Gene Ruler 100-bp DNA Ladder; Fermentas); lane $\mathrm{K}$, negative control (no DNA); lane 1, Eutypella prunastri (CBS. 277.87); lane 2, Eutypa lata (CBS. 208.87); lane 3, E. lata var. aceris (CBS 290.87); lane 4, E. lata var. aceris (CBS 217.87); and lane 5, Eutypella parasitica (SFI D26/1).

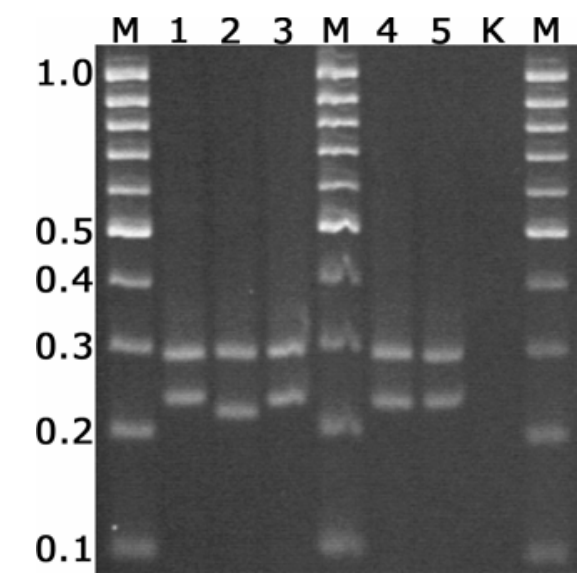

Fig. 3. TaqI restriction fragment length polymorphism patterns of polymerase chain reaction-amplified internal transcribed spacer (ITS)1/5.8S/ITS2 region using primer pair ITS1f/ITS4 from DNA isolated from pure cultures. Digests were run on a $2 \%$ agarose gel in $0.5 \times$ Tris-borate EDTA buffer. Lane M, molecular ladder, Kbp units (Gene Rule 100-bp DNA Ladder; Fermentas); lane $\mathrm{K}$, negative control (no DNA); lane 1, Eutypella prunastri (CBS. 277.87); lane 2, Eutypa lata (CBS. 208.87); lane 3, E. lata var. aceris (CBS 290.87); lane 4, E. lata var. aceris (CBS 217.87); and lane 5, Eutypella parasitica (SFI D26/1).
Several undiluted samples of DNA extracted directly from infected wood with the $2 \%$ CTAB extraction protocol revealed no amplification or only weak amplification with the species-specific primers (EpR and $\mathrm{EpF}$ ); however, after the original DNA extract was diluted, the amplification was successful. An important step in molecular diagnostics is the isolation of DNA free of any DNA amplification inhibitors (25). PCR inhibitors in extracts made from maple tissue were confirmed by PCR reaction with EpR/F using uninfected maple DNA extracts, spiked with serial dilutions of DNA from pure E. parasitica culture. The presence of such compounds probably affected the PCR amplification of DNA extracted directly from infected wood.
Another reason for the weak amplification or no amplification at all could be a low concentration of fungal DNA due to the particular location of tissues taken for the DNA extraction, such as the early-infection area or the edge of an infected lesion. PCR detection with $E$. parasitica-specific primers in extracts made directly from infected maple wood tissue shows rather inconsequential results, as explained previously. These results indicate the need for diluting the original extracts before performing PCR reaction to reduce possible PCR inhibitors present in the sample. Lecomte et al. (24) reported a simple DNA extraction protocol that they used successfully for in situ detection of Eutypa lata in a diseased grapevine. Lecomte's protocol

Table 4. Restriction fragment length polymorphism patterns of polymerase chain reaction (PCR)amplified internal transcribed spacer (ITS) regions (650 bp long) obtained with restriction enzymes HinfI, MboI, and TaqI using primer pair ITS1f/ITS4 from DNA of fungal species or genotypes included in the analysis

\begin{tabular}{llcc}
\hline & \multicolumn{3}{c}{$\begin{array}{c}\text { Length of restriction fragments } \\
\text { of PCR products (bp) }\end{array}$} \\
\cline { 2 - 4 } Species & \multicolumn{1}{c}{ HinfI } & MboI & TaqI \\
\hline Eutypella parasitica (all isolates from Table 1) & $231,156,140,121$ & 319,214 & 289,233 \\
E. parasitica (isolate SFI TO1/1) & $231,156,140,121$ & 319,214 & 289,233 \\
E. prunastri (CBS 277.87) & 345,286 & 319,214 & 289,233 \\
Eutypa lata (CBS 208.87) & $345,151,135$ & 319,214 & 289,217 \\
E. lata var. aceris (CBS 290.87) & $345,151,135$ & 319,214 & 289,233 \\
E. lata var. aceris (CBS 217.87) & $345,151,135$ & 319,214 & 289,233 \\
\hline
\end{tabular}

\section{$\begin{array}{lllllllllllllllll}M & 1 & 2 & 3 & 4 & 5 & 6 & 7 & 8 & 9 & 10 & 11 & 12 & 13 & 14 & \mathrm{~K} & \mathrm{M}\end{array}$}

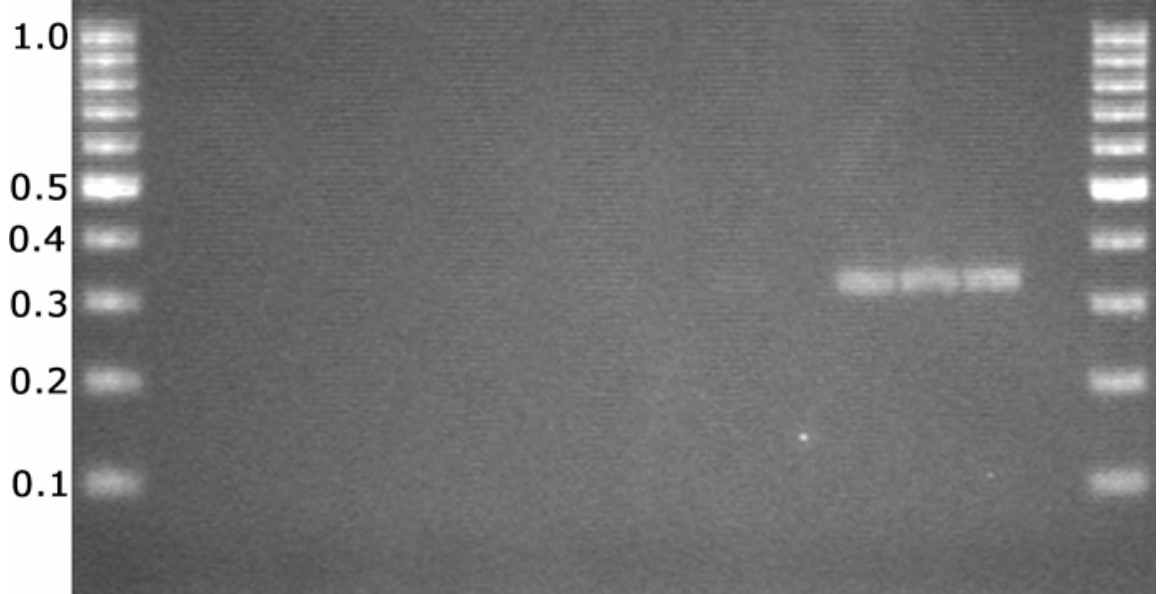

Fig. 4. Products of polymerase chain reaction (PCR) amplification at annealing temperature of $63^{\circ} \mathrm{C}$ with primers EpR/F from DNA isolated from pure fungal cultures of some members of Diatrypaceae and isolates co-isolated from wood beneath Eutypella canker. PCR products were run on a $2 \%$ agarose gel in $0.5 \times$ Tris-borate EDTA buffer. Lane M, molecular ladder, Kbp units (Gene Ruler 100-bp DNA Ladder; Fermentas); lane K, negative control (no DNA); lane 1, Acremonium sp. (SFI TBR1); lane 2, Chaetomium globosum (SFI C/1); lane 3, Nectria galligena (SFI Nectria/1); lane 4, N. galligena (SFI Nectria/2); lane 5, Exophiala sp. (SFI PBR/1); lane 6, Schyzophyllum commune (SFI E/1); lane 7, Exophiala sp. (SFI E/2); lane 8, Eutypella prunastri (CBS. 277.87); lane 9, Eutypa lata (CBS. 208.87); lane 10, E. lata var. aceris (CBS 290.87); lane 11, E. lata var. aceris (CBS 217.87); lane 12, Eutypella parasitica (SFI D26/1); lane 13, E. parasitica (SFI TO1/1); and lane 14, E. parasitica (CBS 210.39). 
(24) also was tested in our study as the method for direct extraction of DNA from infected maple wood. This method did not work in the subsequent PCR with the wood shavings included in our experiment-either with universal fungal primers or with those specific to Eutypella parasitica. A possible explanation for this outcome is that our samples contained larger amounts of PCR inhibitors or smaller amounts of DNA than those used by Lecomte et al. (24).

The species-specific EpR/F primers constructed during this work proved adequate to distinguish $E$. parasitica from Eutypa lata and E. lata var. aceris, which is difficult to accomplish using only morphological features of their mitosporic stage. As reported by the CBS database and Carter et al. (4), such fungi can be present in wood of Acer spp. Applied techniques successfully differentiate between Eutypella prunastri and E. parasitica, which are both representatives of the same taxonomic unit based on morphological features. This is another confirmation of successful application of the EpR/F primer pair in identification of fungi. The biology of Diatrypaceae species is not well known, the taxonomy not settled, and phylogenetical position of E. parasitica not clear (36). These reasons obstruct easy identification. The proposed method will facilitate proper identification of the causal agent of the cankers of maple, although Eutypa lata or any other Diatrypaceae species have not been reported so far as being pathogenic to maple.

The cankers caused by Eutypella parasitica are morphologically similar to those caused by Botryosphaeria dothidea

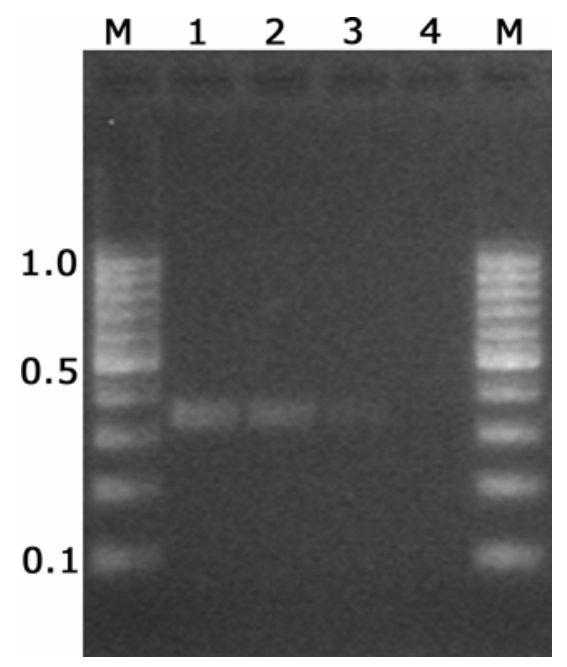

Fig. 5. Polymerase chain reaction (PCR) detection of Eutypella parasitica in infected wood tissue at the margins of the discolorations with primers $\mathrm{EpR} / \mathrm{F}$ at annealing temperature of $63^{\circ} \mathrm{C}$. PCR products were run on a $2 \%$ agarose gel in $0.5 \times$ Tris-borate EDTA buffer. Lane M, molecular ladder, Kbp units (Gene Ruler 100-bp DNA Ladder; Fermentas); lane 1, undiluted DNA extract; lane 2, 100-fold diluted DNA extract; lane 3, 1,000-fold diluted DNA extract; and lane 4, 10,000-fold diluted DNA extract. (mostly on A. platanoides) and Nectria galligena (mostly on A. pseudoplatanus) found in Slovenia (unpublished observations). However, the tested primers specific to E. parasitica successfully distinguished between the different causal agents of the canker. Robustness of EpR/F primers also was confirmed by their ability to distinguish isolates of $E$. parasitica from those of Acremonium spp., Chaetomium globosum, Exophiala spp., and N. galligena, obtained from cankers on maple, and other ubiquitous ascomycetes and basidiomycetes or those associated with woody tissues.

PCR-RFLP represents a relatively rapid and simple method that has been used successfully for species identification and separation in many plant groups $(3,32)$, identification of ectomycorrhizae (2,9$11,18,20-22)$, and identification of fungi that cause wood decay (15). It also has been used to distinguish among species, as in the case of Armillaria spp. by Schulze et al. (38), to study intraspecific variation in A. ostoyae (37), and also for identification of Eutypa lata, another member of Diatrypaceae (36). The results obtained through the sequencing and RFLP profiling show highly conserved ITS regions of the collected Eutypella parasitica isolates and indicate low intraspecific variability in the ITS1/5.8S/ITS2 region. Intraspecific polymorphism was not detected among Eutypa lata isolates when examined with PCRRFLP of the ITS region (36). The RFLP patterns in Eutypella parasitica point to an autonomous cluster in the SFI PCR-RFLP database in comparison with the previously deposited RFLP patterns. The PCRRFLP method used in this study was specific enough to distinguish $E$. parasitica from E. prunastri, Eutypa lata, another pathogenic member of Diatrypaceae, and from two isolates of E. lata var. aceris.

Thus, molecular methods are feasible as additional tests to supplement the classical identification protocols or as independent identification methods for forest pathogens in Slovenia, as was indicated also by Jurc et al. (16) and reinforced in this study.

\section{ACKNOWLEDGMENTS}

The study was financed by the Ministry of Higher Education, Science and Technology of Republic of Slovenia; the Ministry of Agriculture, Forestry and Food of Republic of Slovenia; and the Slovenian Research Agency through the research program P4-0107 (Forest Biology, Ecology and Technology), Young Researcher Scheme for B. Piškur and research projects no. V4-0352 and L4985-040-06. The molecular studies were done in the laboratory of the Department for Forest Physiology and Genetics of SFI under supervision and with support of $\mathrm{H}$. Kraigher and T. Grebenc. We thank F. Pohleven (Department of Wood Science and Technology, Biotechnical Faculty, Ljubljana) and A. Gregori (Institute of Natural Sciences, Ljubljana) for providing us with valuable reference isolates; V. Rajh, B. Stupar, and M. Hrenko for technical support; and T. Grebenc for a thorough review and useful remarks that improved this manuscript.

\section{LITERATURE CITED}

1. Acero, F. J., González, V., Sánchez-Ballestros, J., Rubio, V., Checa, J., Bills, G. F., Salazar, O., Platas, G., and Peláez, F. 2004. Molecular phylogenetic studies on the Diatrypaceae based on rDNA-ITS sequences. Mycologia 96:249-259.

2. Agerer, R., Kraigher, H., and Javornik, B. 1996. Identification of ectomycorrhizae of Hydnum rufescens on Norway spruce and the variability of the ITS region of $H$. rufescens and $H$. repandum (Basidiomycetes). Nova Hedwigia 63:183-194.

3. Ballian, D., Grebenc, T., Božič, G., Melnik, V., Wraber, T., and Kraigher, H. 2006. History, genetic differentiation and conservation strategies for disjunct populations of Sibiraea species from Southeastern Europe and Asia. Conserv. Genet. 7:895-907.

4. Carter, M. V., Bolay, A., and Rappaz, F. 1983 An annotated host list and bibliography of Eutypa armeniacae. Rev. Plant Pathol. 62:251258.

5. Davidson, R. W., and Lorenz, R. C. 1938. Species of Eutypella and Schizoxylon associated with cankers of maple. Phytopathology 28:733-745

6. Doyle, J. J., and Doyle, J. L. 1987. A rapid DNA isolation procedure for small quantities of fresh leaf tissue. Phytochem. Bull. 19:11-15.

7. Gardes, M., and Bruns, T. D. 1993. ITS primers with enhanced specificity for basidiomycetes-application to the identification of mycorrhizae and rusts. Mol. Ecol. 2:113-118.

8. Ghignone, S., and Migheli, Q. 2005. The database of PCR primers for phytopathogenic fungi. Eur. J. Plant Pathol. 113:107-109.

9. Grebenc, T. 2005. Types of ectomycorrhizae on beech (Fagus sylvatica L.) in natural and managed forest. Ph.D. thesis, University of Ljubljana, Ljubljana, Slovenia.

10. Grebenc, T., and Kraigher, H. 2000. Establishment of the PCR-ITS-RFLP database for mycorrhizal fungi and types of ectomycorrhizae on Norway spruce from the permanent forest research plot of the Slovenian Forestry Institute on Pokljuka. Pages 179-190 in: The Rhizosphere: Studies of Forest Soils and the Rhizosphere and Their Influences on Chosen Physiological Parameters of Forest Trees in Selected Forest Ecosystems, Forest Types and Developmental Phases of the Forest. $\mathrm{H}$. Kraigher and I. Smolej, eds. Slovenian Forestry Institute, Ljubljana, Slovenia.

11. Grebenc, T., and Kraigher, H. 2007. Changes in the community of ectomycorrhizal fungi and increased fine root number under adult beech trees chronically fumigated with double ambient ozone concentration. Plant Biol. (Stuttg.) 9:279-287.

12. Grebenc, T., Piltaver, A., and Kraigher, $\mathrm{H}$. 2000. Establishment of a PCR-RFLP library for Basidiomycetes, Ascomycetes and their ectomycorrhizae in Picea abies (L.) Karst. Phyton (Horn) 40:79-82.

13. Grebenc, T., Rupnik, M., Hacin, J. I., Janc, M., and Kraigher, H. 1999. A contribution to the studies of actinorrhizal symbioses of Alnus spp. in Slovenia. Phyton (Horn) 39:207-211.

14. Grimont, P. A. D. 1998. Taxotron User's Manual. Institute Pasteur, Paris.

15. Jellison, J., and Jasalavich, C. 2000. A review of selected methods for the detection of degradative fungi. Int. Biodeterior. Biodegrad. 46:241-244.

16. Jurc, D., Ogris, N., Grebenc, T., and Kraigher, H. 2006. First reported Botryosphaeria dothidea causing bark dieback of European hop hornbeam in Slovenia. Plant Pathol. 55:299.

17. Jurc, D., Ogris, N., Slippers, B., and Stenlid, J. 2006. First report of Eutypella canker of Acer pseudoplatanus in Europe. Plant Pathol. 55:577.

18. Kåren, O., Hogberg, N., Dahlberg, A., Jonsson, 
L., and Nylund, J. E. 1997. Inter- and intraspecific variation in the ITS region of rDNA of ectomycorrhizal fungi in Fennoscandia as detected by endonuclease analysis. New Phytol. 136:313-325.

19. Kliejunas, J. T., and Kuntz, J. E. 1974. Eutypella canker, characteristics and control. For. Chron. 50:106-108.

20. Kraigher, H. 1994. Molecular ecology in forestry: taxonomy of ectomycorrhizae by anatomical characteristics and molecular markers. Pages 189-196 in: Proc. Int. Colloquium Impact Plant Biotechnol. Agric. Rogla, Slovenia. B. Javornik, B. Bohanec, and I. Kreft, eds. Biotechnical Faculty, Agronomy Department, Centre for Plant Biotechnology and Breeding, Ljubljana, Slovenia.

21. Kraigher, H., Agerer, R., and Javornik, B. 1995. Ectomycorrhiza of Lactarius lignyotus on Norway spruce, characterized by anatomical and molecular tools. Mycorrhiza 5:175180.

22. Kraigher, H., Batič, F., and Agerer, R. 1996. Types of ectomycorrhizae and mycobioindication of forest site pollution. Phyton (Horn) 36:115-120.

23. Lachance, D., and Kuntz, J. E. 1966. Eutypella canker of sugar maple. Phytopathology 56:885-886.

24. Lecomte, P., Péros, J. P., Blancard, D., Bastien, N., and Délye, C. 2000. PCR assays that identify the grapevine dieback fungus Eutypa lata. Appl. Environ. Microbiol. 66:4475-4480.

25. Malvick, D. K., and Grunden, E. 2005. Isola- tion of fungal DNA from plant tissues and removal of DNA amplification inhibitors. Mol. Ecol. Notes 5:958-960.

26. McCartney, H. A., Foster, J. S., Fraaije, B. A., and Ward E. 2003. Molecular diagnostics for fungal plant pathogens. Pest Manage. Sci. 59:129-142.

27. Morgenstern, B. 1999. DIALIGN 2: improvement of the segment-to-segment approach to multiple sequence alignment. Bioinformatics 15:211-218.

28. Munkvold, G. P. 2001. Eutypa dieback of grapevine and apricot. Plant Health Progress Online, doi: 10.1094/PHP-2001-0219-01-DG.

29. OEPP/EPPO. EPPO Alert List. Entry date 2005-11. Online publication, 2005.

30. Ogris, N., Jurc, D., and Jurc, M. 2005. Eutypella canker (Eutypella parasitica: Ascomycota: Fungi) on sycamore maple and field maple: characteristics and differences. Gozd. Vestn. 63:411-418.

31. Ogris, N., Jurc, D., and Jurc, M. 2006. Spread risk of Eutypella canker of maple in Europe. Bull. OEPP 36:475-485.

32. Pučko, M., Grebenc, T., Božič, G., Brus, R., and Kraigher, H. 2005. Identification of types of ectomycorrhizae on seedlings in a beech provenance trial. Zb. Gozd. Lesar. 75:87-104.

33. Raspor, P., Smole-Možina, S., Podjavoršek, J., Pohleven, F., Gogala, N., Nekrep, F. V., Rogelj, I., and Hacin, J. 1995. ZIM, the Collection of the Industrial Microorganisms. Catalog of biocultures. Biotechnical Faculty, Ljubljana, Slovenia.
34. Riley, M., Maling, B., and Chamberlin, M. J. 1966. Physical and chemical characterization of two- and three-stranded adenine-thymine and adenine-uracil homopolymer complexes. J. Mol. Biol. 20:118-124.

35. Rogers, S. O., and Bendich, A. J. 1985. Extraction of DNA from milligram amounts of fresh, herbarium and mummified plant tissues. Plant Mol. Biol. 5:69-76.

36. Rolshausen, P. E., Trouillas, F., and Gubler, W D. 2004. Identification of Eutypa lata by PCRRFLP. Plant Dis. 88:925-929.

37. Schulze, S., Bahnweg, G., Möller, E. M., and Sandermann, Jr. H. 1997. Identification of the genus Armillaria by specific amplification of an rDNA-ITS fragment and evaluation of genetic variation within $A$. ostoyae by rDNARFLP and RAPD analysis. Eur. J. For. Pathol. 27:225-239.

38. Schulze, S., Bahnweg, G., Tesche, M., and Sandermann, Jr. H. 1995. Identification of European Armillaria species by restrictionfragment-length polymorphisms of ribosomal DNA. Eur. J. For. Pathol. 25:214-223.

39. Sinclair, W. A., Lyon, H. H., and Johnson, W. T. 1989. Diseases of Trees and Shrubs. Cornell University Press, New York.

40. White, T. J., Bruns, T., Lee, S., and Taylor, J. 1990. Amplification and direct sequencing of fungal ribosomal RNA genes for phylogenetics. Pages 315-322 in: PCR Protocols. A Guide to Methods and Applications. M. A. Innis, D. H. Gelfand, J. J. Sninsky, and T. J. White, eds. Academic Press, San Diego, CA. 